animal bones, a large number of potsherds and a few stone, silver, and bronze implements. Nothing of gold was found, and only half a dozen small silver pins and pendant dises.

The city itself contains about two hundred edifices. Most of the walls are standing and many of the terraces are in good repair. The roofs of the houses disappeared long since, and a large part of the city was completely overgrown with a tropical forest. Trees $2 \mathrm{ft}$. in diameter were found growing on top of the walls of the houses, and in some cases on the very peaks of the gables. A majority of the houses are of a storey and a half in height with gable ends.

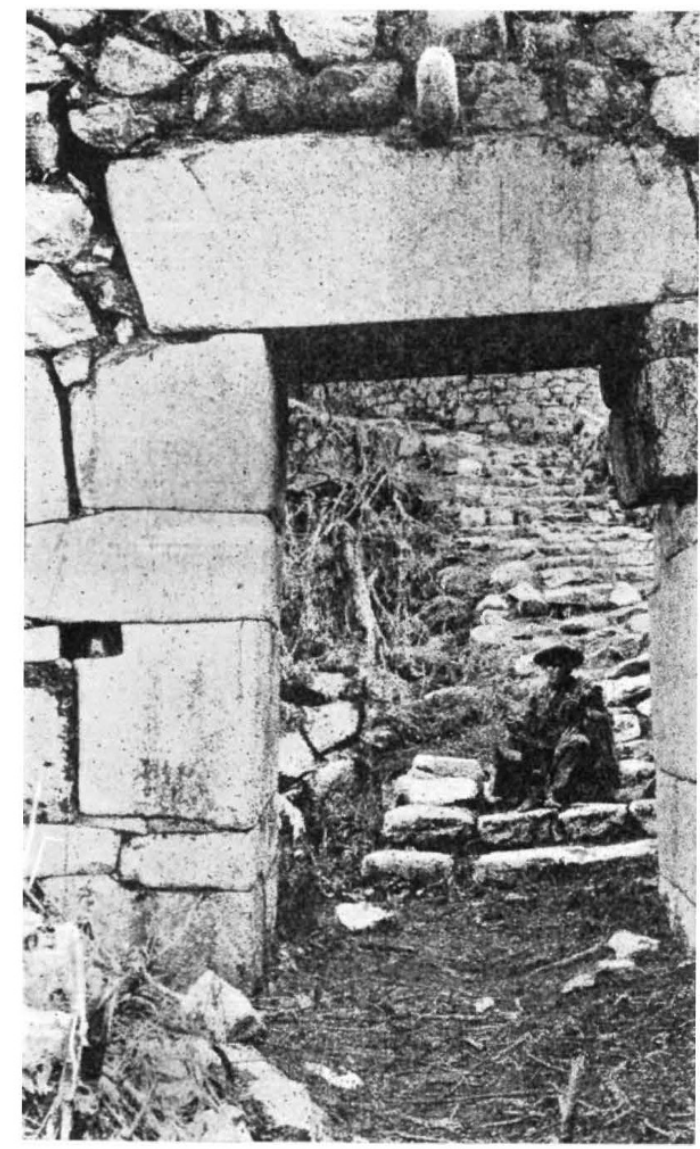

FIG. 5.-Machu Picchu. City gate, interior. Notice the lock hole containing granite cylinder on left and projecting ring stone over the lintel of the doorway. The gate, probably of wood, was either swung from the ring stone or fastened to it and balanced by a log fastened to the stone cylinders in the lock hole on either side of the gateway. A similar device was used also in the entrance doors to each isolated group of houses. Copyright by the National Geographic Society.

Perhaps the most conspicuous features of Machu Picchu are the number of stairways and the large number of windows in the houses. There are more than a hundred stairways, large and small, within the city. Some of them have more than 150 steps. In some cases the entire stairway of from six to ten steps was cut out of a single granite boulder. The water supply must always have been very scarce. We were there during the dry season, and with forty workmen found the available springs only barely sufficient for cooking and drinking purposes. The town may have had a population of two thousand people on occasion.

In the four months of field season, the ruins were practically cleared of all forest growth, and a large part of the débris was burned and removed. From twenty to forty workmen were kept continuously at work under the direction of Mr. Erdis.

One of the most interesting facts brought out as a result of the clearing was that the city was at one time divided into wards, or clan groups, each of which had but one entrance, a gateway furnished with the means of being solidly fastened on the inside. Each one of the clan groups has certain distinctive features, one having its own private gardens, another being distinguished by the ingenuity of the stone work, while still another is marked by having monolithic lintels over the doorways, and unusually steep gables. Nachu Picchu contains examples of nearly every variety of architecture known to the Incas and their predecessors on the Peruvian highlands, including fine specimens of the most exquisite stone cutting that can be found anywhere in the New World. One of the most interesting structures is a temple containing three conspicuously large windows. Another is composed of several large blocks of granite, three of them being more than $12 \mathrm{ft}$. in length. These are shown in the accompanying photographs.

Machu Picchu is in a remarkably good state of preservation, and its architecture has not become confused by Spanish efforts to build churches and villas. The people who lived here were masters of the art of stone cutting. They know how to make bronzes, and they had considerable artistic sense. Their pottery is characteristically Inca in form and ornamentation, but some of the patterns and shapes are practically unknown in European museums.

Just where Machu Picchu comes in the history of the Incas is still a puzzle. It is too early to speak definitely. In many ways it appears to be closely related to Cuzco. One of the buildings bears a strong resemblance to the famous Temple of the Sun, now the Dominican Monastery. It is safe to say that Machu Picchu was essentially a city of refuge. There is no part of the Andes better defended by nature than this Grand Canon of the Urubamba. Granite precipices, frequently more than $1000 \mathrm{ft}$. sheer, present difficulties of attack and facilities for defence which cannot be excelled. Furthermore, the natural defences were strengthened by the construction of high walls and a dry moat.

A careful survey of the ruins and the neighbouring cañon was made by Mr. Stephenson. More than seven hundred photographs of the ruins were taken by the writer, who has in hand the preparation of a complete report on the ruins and the material collected at Machu Picchu.

Hiram Bingham.

\section{CIVIL SERVICE ESTIMATES FOR SCIENCE AND EDUCATION.}

THE Estimates for Civil Services for the year ending March $3 \mathrm{I}, \mathrm{I}^{\mathrm{I}} 5$, are being issued as a series of Parliamentary Papers. The following particulars referring to the money under this heading to be devoted to scientific work and to higher education are taken from the paper entitled, "Class IV.-Education, Science, and Art."

Under the heading, "Scientific Investigation, etc.," we find that the grants in aid for I9I4-15 amount to roo, $69-l$., which represents a net decrease of $i \mathrm{l} l$. on the amount voted in $1913^{-14}$.

The grants enumerated under the heading of the Royal Society amount for $x 9 \mathrm{I}_{4}-15$ to $25,550 l$, as compared with $27,150 l$ in $1913-14$. This grant includes the usual $4000 \%$. in aid of scientific investigation and roool. for scientific publications; the remainder of the amount is for the expenses of the Magnetic Ob. 
servatory at Eskdalemuir, and for the National Physical Laboratory. For salaries and other expenses of the National Physical Laboratory the grant for 1914-15 is 7oool., as compared with $12,000 l$. in I913-I4; but the grant for the Aeronautical Section of the National Physical Laboratory, which is given separate mention, is for $1914^{-1} 5 \mathrm{I} 2,550 l$., as compared with $9150 l$. in $1913-14$.

The following grants remain as they were in r9I314 :- Meteorological Office, 20,oool. ; Royal Geographical Society, I,25ol.: Marine Biological Association of the United Kingdom, roool. ; Royal Society of Edinburgh, 6ool.; Scottish Meteorological Society, rool.; Royal Zoological Society of Ireland, 5ool.; Royal Scottish Geographical Society, 20ol.; International Geodetic Association, 3ool.; Solar Physics Observatory, 300ol. ; North Sea Fisheries Investigation, $1250 l$; International Seismic Association, $2 \mathrm{Iol}$.

The grant to the Edinburgh Observatory is 1637 ., an increase of $89 l$. on I9I3-I4; and the British Antarctic Expedition receives $5000 l$. for the year $19 \mathrm{I}^{-1}{ }_{5}$.

The grants in aid of the expenses of universities and university colleges amount for the year under consideration to $287,000 l$., precisely the same sum as in the previous year.

The vote for science and art in Ireland reaches $145,164 l$, as compared with $140,450 l$. in the previous year, a net increase of $4,7 \times 4 l$. The estimate of the amount required for grants under the Irish University Act, 1908, is $124,000 l$., a decrease of $1800 l$.

The estimate of the amount required to pay the salaries and expenses of the Board of Education and of the various establishments connected therewith is $14,730,621 l$., a net increase of $70,55^{2 l}$. Among the items included in this large sum the following are of interest in this connection :- Technical institutions and evening schools, $638,000 l$, an increase of 23,200l.; university institutions in respect of technological work, $48,000 l$., an increase of $2000 l$. ; Imperial College of Science and Technology, 30,0ool.; Science Museum, $2 \mathrm{x}, 322 \mathrm{l}$., an increase of $2895 \mathrm{l}$.; Geological Museum, $3925 l$., an increase of $176 l$.; and the Geological Survey, 16,828l., a decrease of $1047 l$.

\section{UNIVERSITY AND EDUCATIONAL} INTELLIGENCE.

GLASGOW.-The first award of the Kelvin gold medal and prize (founded by Lady Kelvin), for the best dissertation in natural philosophy presented for the degree of D.Sc. during the three years I9II-I3, has been made to Dr. A. D. Ross, now professor in the University of Western Australia.

The first award of the William Jack prize (founded in honour of Emeritus Professor Jack), for the best dissertation in mathematics presented for the degree of D.Sc. during the four years $\mathrm{IgIO}^{-1} 3$, has been made to Dr. R. J. T. Bell, senior University lecturer in mathematics.

LeEds.-Mr. Aldred F. Barker, who has been head of the textile department of the Bradford Municipal Technical College for twenty years, has been appointed to succeed Mr. Roberts Beaumont as professor of textile industries. Mr. Barker is an old student of the University, having worked under Prof. J. Beaumont, the first occupant of the chair to which he now succeeds. He has had a considerable experience of actual mill work, and his publications are recognised as standard works on textiles.

Mr. Robert Cattley has been appointed honorary fellow in pathology, and Mr. Lionel Walmsley as honorary curator of the Marine Laboratory, Robin Hnod's Bay.

No. 23I7, vol. 93]
Mr. F. J. NorTH, assistant in the geological laboratory, King's College, London, has been appointed assistant keeper in the department of geology in the National Museum of Wales.

A course of lectures on arts of East and West, by Laurence Binyon, will be given at the Battersea Polytechnic, London, S.W., on Wednesdays at 6 p.m., be:ginning May 6 . The lectures are intended for advanced students; admission is free, and no ticket is required.

Mr. Percy Coleman, of the Northern Polytechnic Institute, Holloway, who has been appointed adviser in technical education and secretary to the National Board for Technical Education in the Union of South Africa, leaves for South Africa in the R.M.S. Kinfauns Castle on April II.

A Summer School in Geography will be held on August 2-22 next at the University College of Wales, Aberystwyth. Prof. H. J. Fleure, lecturer in geography at the college, will give ten lectures on a regional survey of Europe, and eight on England and Wales. Mr. W. E. Whitehouse will give eight lectures on the teaching of geography by modern methods, five on the climate of the British Isles, and five on mathematical geography. In addition to the courses of lectures, practical work will be taken daily. Field classes will be held for practice in the use of simple survey instruments, while excursions will be made to places of interest, which afford material for the study of land sculpture, vegetation, and human facts.

We learn from the Times that in accordance with a resolution passed at the joint meeting of the German and English sections of the King Edward VII. British-German Foundation, instituted by Sir Ernest Cassel, the German Foundation will again, in the year I9I4-I5, use part of its income in providing studentships to enable university graduates of British nationality to reside in Germany with the object of studying some branch of science or literature, or becoming acquainted with the commercial or indus trial life of the country. The work of selection was even more difficult than last year, as the number of candidates was far larger, and most of them had obtained first-class honours in their universities. Studentships of the value of about $\mathrm{r}_{75} l$. were on March 21 awarded to Mr. B. Dickins, Magdalene College, Cambridge; Mr. R. A. Frazer, Pembroke College, Cambridge: Mr. S. W. Rawson, Queen's College, Oxford; Mr. G. G. Williams, Christ Church, Oxford; Mr. F. P. Wilson, Birmingham University and Oxford University; Mr. T. Wright, King's College, London University. Studentships of the value of about iool. were awarded to Mr. A. B. Mayne, Balliol College, Oxford; Mr. J. S. Stephens, St. John's College, Cambridge.

\section{SOCIETIES AND ACADEMIES. LONDON.}

Geological Society, March $x$ x.-Dr. A. Smith Woodward, president, and afterwards Dr. H. H. Bemrose, vice-president, in the chair.--E. T. Newton: A series of small mammalian and other remains from the rockshelter of La Colombière, near Poncin (Ain). During the ycar IgI3, Dr Lucien Mayet and M. Jean Pissot were working systematicallv at the prolific deposits of this locality, and towards the end of the year made known the discovery of a number of incised bones and stones, representing the human form as well as several animals. The upper part of the deposit is referred to the Neolithic and Magdalenian ages; but 